\title{
Watersheds, Anthropogenic Activities and the Role of Adaptation to Environmental Impacts
}

\author{
Fernando António Leal Pacheco ${ }^{1, *(1)}$ and Luís Filipe Sanches Fernandes ${ }^{2}$ (i) \\ 1 CQVR-Centro de Química de Vila Real, Universidade de Trás-os-Montes e Alto Douro, Ap. 1013, \\ 5001-801 Vila Real, Portugal \\ 2 CITAB-Centro de Investigação e Tecnologias Agroambientais e Biológicas, Universidade de Trás-os-Montes \\ e Alto Douro, Ap. 1013, 5001-801 Vila Real, Portugal; lfilipe@utad.pt \\ * Correspondence: fpacheco@utad.pt
}

Received: 25 November 2020; Accepted: 7 December 2020; Published: 9 December 2020

Runoff has shaped the Earth into watersheds, and humans have appropriated many of them. Since then, societies have settled on and used the watersheds and their resources to develop activities aiming at welfare. A vital resource is stream water, fed by the surface and underground compartments. However, overexploitation, contamination by humanity and climate variations reduce the availability of water for the targeted uses (e.g., drinking water and irrigation), endangering expected well-being besides the surrounding ecosystems. Hydrologic and statistical modeling have been used to assess the impacts of humans on the quality of water. Some studies refer to the consequences for water quality of point-source contamination, namely, direct discharges into streams of untreated or poorly treated domestic or industrial effluents [1]. Other work relates water quality degradation with diffuse pollution sources, considering the complementary role of natural processes such as soil erosion [2,3]. There is also a great deal of research where a nexus is established between anthropogenic activities, poor water quality and ecological integrity degradation [4-9]. With the purpose of helping in developing and implementing strategies for the mitigation of negative anthropogenic impacts and conservation of water quality in catchments, some studies have explored the controlling factors for contaminant propagation, at the regional (catchment) or local (reach) scales. That has included the influences of the season, scale, landscape configuration and share of riparian vegetation along the streams, among others [10-14].

Humanity also interferes with the hydrology of streams and rivers through changes in land use, including urbanization, forest-agriculture conversions or other impacting actions. The consequences for water resources and watershed management are numerous, including changes in the share of water balance components (e.g., surface flow, infiltration/groundwater flow, and evapotranspiration), potential water scarcity problems derived therefrom, hydromorphological changes in stream banks and urban floods [15-18]. This disturbance may be amplified by climate variations, leading to the need for anticipating adaptation or mitigation measures. A diversity of approaches to adaptation to water scarcity have been proposed to date, depending on the targeted water use. In the rural environment, the alternatives comprise the storage of rainwater in small dam lakes (rainwater harvesting), to be used in the irrigation of cropland or combating wildfires [19,20]. In the urban environment, especially around the large metropolises, the conjunctive use of various sources (surface water, groundwater, desalinized water and recycled wastewater) can be a reliable path to adaptation, aided by controlled groundwater recharge where possible [21-25]. The incentive to produce clean drinking water in headwater catchments through the adaptation of land uses (e.g., a shift from extensive monocultures to agro-forestry systems), aiming at the reduction of treatment and hence final costs, is a promising adaptation measure. However, the implementation of these land use and land cover (LULC) changes is challenging because it presupposes the payment for this environmental service. The landowners should 
receive the incentive from the final consumers, but the value is not easy to define, and the procedure is difficult to implement [26]. The control of floods has been practiced by the use of detention basins (structural interventions) and LULC changes such as forestations (non-structural measures) $[27,28]$. They both have advantages and disadvantages. Some authors argue that, for larger floods, the detention of river water in a large dam is essential to attain the objective of reducing or suppressing the inundated areas and their negative environmental, economic and social consequences [29].

The consequences of anthropogenic activities for watersheds are particularly addressed in this Special Issue, "Impacts of Anthropogenic Activities on Watersheds in a Changing Climate". In that regard, this Special Issue explores the impacts of human activities on the water quality and hydrology of streams and reservoirs, on hydromorphologic changes along river channels and on urban floods. It also discusses prominent factors controlling freshwater quality at the watershed and reach scales. Finally, it proposes adaptation measures to mitigate water scarcity in catchments and water quality degradation for drinking water supplies. During our working period, we received many submissions, which presented significant contributions for the main topics of interest of our Special Issue. However, only 12 high-quality papers were accepted after several rounds of strict and rigorous review. These 12 contributions are summarized in the forthcoming paragraphs, being integrated in a coherent narrative.

Contribution 1 discussed the impact of urban heat islands on the temperatures of rivers crossing cities. The authors studied the Suceava River (Romania) water temperature and concluded about a general increase downstream of Suceava city. They also observed daily water temperature profiles with steeper slopes and earlier moments of the maximum and minimum temperatures than upstream, which were considered a consequence of urban heat islands. Contribution 2 used Landsat series images from 1980 to 2015 and Structural Equation Models to investigate the diverse impacts of climatic and anthropogenic variables on nearly two hundred lakes and reservoirs widespread in the Nenjiang watershed (China). The observations allowed documenting a $42 \%$ decline in the total area and $51 \%$ in the number of lakes from 1980 to 2010, and a slight increase in these parameters afterwards. The statistical models exposed a strong relationship between the lake changes and the mean annual precipitation falling over the watershed, not ruling out the contribution of the agricultural consumption of water. Contribution 3 described the impacts of land use and land cover (LULC) changes on river flow rates and morphologies using the Reno River as a representative example. The Reno's watershed was characterized by forest exploitation and agricultural production until World War II, but the progressive abandonment of agriculture since then converted the catchment's occupation into meadows, forests and uncultivated land. These LULC changes produced reductions in the river flow rate and suspended sediment yield ( $-36 \%$ and $-38 \%$, respectively). These reductions produced a $40-80 \%$ decline in the riverbed area, a development of vegetation in the riparian buffer strips and a river channel change from a braided to single channel. Contributions 4 and 5 both studied the impacts of LULC on flow components. In the first case, the work was carried out in the Sabor River Basin (Portugal), and the authors investigated the roles of afforestation as well as of wildfires. While afforestation resulted in decreases in water yield, surface flow and groundwater flow and increases in evapotranspiration and lateral flow, wildfires caused an increase in surface flow and a decrease in lateral flow. In the second case, the studied area was the Yiluo River Basin (Middle Yellow River), and the aim was to investigate the roles of LULC and river regulation actions. In regard to LULC, the results showed that increased areas of urban land and decreased areas of vegetation land resulted in a decrease in both groundwater and evapotranspiration, but an increase in average surface runoff. Besides, the expansion of water areas resulted in an increase in evapotranspiration but had little effect on groundwater and surface runoff. Contribution 6 investigated the impact of LULC change on floods, focusing the analysis on a specific type of change characterized by the conversion of a natural use to one disrespecting land capability. This type of conversion is said to trigger environmental land use conflicts that are capable of amplifying environmental impacts, namely, floods. In the studied area (Batatais town, state of São Paulo, Brazil), the authors estimated that approximately $60 \%$ of areas were affected by these conflicts. The results 
helped explaining the severe floods that affect the city recurrently. They also supported the proposal of preventive and recovery measures in the context of a land consolidation-water management plan.

Contributions 1 to 6 describe anthropogenic activities developed on watersheds from around the planet, and the environmental impacts derived therefrom. Following this first group of contributions, a set of three other studies discuss the drivers and factors controlling the aforementioned impacts. Contribution 7 used Partial Least Squares-Path Models (PLS-PM) to investigate the effects on stream water quality of the landscape configuration, season, and distance from contaminant emissions from diffuse and point sources. The study was carried out in the Ave River Basin (Portugal). Overall, the PLS-PM results evidenced significant cause-effect relationships between landscape metrics and stream water quality (e.g., chemical and biochemical oxygen demands, and nitrogen and phosphorus emissions from the diffuse and point sources) at $10 \mathrm{~km}$ or larger scales, regardless of the season. Contribution 8 analyzed the effects of 15, 30 and 50 m-wide riparian forest on the water quality (e.g., turbidity) of three headwater catchments located in the EPA-URB-Environmental Protection Area of Uberaba River Basin (state of Minas Gerais, Brazil), which was legally protected for the conservation of water resources but is extensively used for sugar cane production. The results suggest that these vegetative barriers are not wide enough to preserve the legally protected water resources. Contribution 9 was also conducted in the EPA-URB. It expanded the analysis of Contribution 8 by exploring the combined effect of landscape composition and buffer strip width (L) on stream water quality. The landscape composition was assessed by the forest $(\mathrm{F})$ to agriculture $(\mathrm{A})$ ratio $(\mathrm{F} / \mathrm{A})$ derived from EPA-URB's LULC map. The water quality was evaluated by an index (IWQ) expressed as a function of physico-chemical parameters. The combined effect, F/A $\times$ L, was quantified by multiple regressions with interaction terms. According to the authors, the interaction between F/A and L reduced the range of $\mathrm{L}$ values required to sustain the IWQ at a fair level by about $40 \%$, relative to models where the terms were ignored. Notwithstanding the interaction, the calculated L ranges $(45-175 \mathrm{~m})$ required for a fair level of IWQ are much larger than the maximum width imposed by the Brazilian laws (30 $\mathrm{m})$.

The last group of contributions to the Special Issue addressed topics related to the monitoring and planning of anthropogenic activities, as well as their impacts and mitigation or adaptation measures. Contribution 10 was a companion paper of Contribution 1 and presented the monitoring of the water level, specific conductivity, dissolved oxygen, oxidation-reduction potential and $\mathrm{pH}$ of the Suceava River for 365 days (2018-2019, with an hourly sampling frequency). As mentioned above, Suceava city is an urban heat island that affects the temperature of the Suceava River. The aim of Contribution 10 was to assess the diurnal cycle of other parameters to determine if they were also impacted by Suceava city. The results made it evident that the specific conductivity is higher downstream of the city (yearly averages: $483.1 \mu \mathrm{S} / \mathrm{cm}$ upstream and $549 \mu \mathrm{S} / \mathrm{cm}$ downstream) because of both treated and untreated waters being discharged directly or indirectly into the watercourse. Contribution 11 addressed the mapping of groundwater recharge from a management standpoint, being developed in the Pandeiros River Basin (state of Minas Gerais, Brazil). The immediate goal was to delineate areas with the maximum potential for recharge that could be protected from human activities and the pollution derived therefrom, for example, through LULC conversions (e.g., an extensive monoculture to agro-forestry system), and at the same time are prepared for the implementation of artificial recharge measures (e.g., the LULC conversions plus the construction of small dams). The last study (Contribution 12) frames the improvement of groundwater recharge in the topics of water security and payment for environmental services. The work took place in the Olaria Stream Basin (state of São paulo, Brazil) and involved the monitoring of stream flow discharge in three small headwater sub-basins. During the monitoring program, one sub-basin underwent recovery from antecedent gully erosion, reforestation with native trees along the drainage network, and conversion from an agricultural area into an agro-forestry system. For that sub-basin, the monitoring results revealed an increase in the stream flow discharge, which was related to the increase in recharge and explained by the aforementioned management practices. The stream flow increase improved the security of the water supply systems of various municipalities fed by these headwater catchments. The study authors 
argued that consumers should be willing to pay the costs faced by the land owners who implemented the management practices, as well as those for their future maintenance, because the stream flow increase was viewed as a service producing more water for public use.

Author Contributions: Both authors participated equally in the preparation and writing of this Editorial. All authors have read and agreed to the published version of the manuscript.

Funding: The author integrated in the CITAB was funded by National Funds of FCT (Portuguese Foundation for Science and Technology) under the project UIDB/04033/2020. The author integrated in the CQ-VR was funded by National Funds of FCT under the projects UIDB/QUI/00616/2020 and UIDP/00616/2020.

Conflicts of Interest: The authors declare no conflict of interest.

\section{List of Contributions:}

1. Briciu, A.-E.; Mihăilă, D.; Graur, A.; Oprea, D.I.; Prisăcariu, A.; Bistricean, P.I. Changes in the water temperature of rivers impacted by the Urban Heat Island: Case study of Suceava City. Water 2020, 12, 1343.

2. Du, B.; Wang, Z.; Mao, D.; Li, H.; Xiang, H. Tracking lake and reservoir changes in the Nenjiang Watershed, Northeast China: Patterns, trends, and drivers. Water 2020, 12, 1108.

3. Pavanelli, D.; Cavazza, C.; Lavrnić, S.; Toscano, A. The long-term effects of land use and climate changes on the hydro-morphology of the Reno River catchment (Northern Italy). Water 2019, 11, 1831.

4. Santos, R.M.B.; Sanches Fernandes, L.F.; Vitor Cortes, R.M.; Leal Pacheco, F.A. Hydrologic impacts of land use changes in the Sabor River basin: A historical view and future perspectives. Water 2019, 11, 1464.

5. Wang, X.; Zhang, P.; Liu, L.; Li, D.; Wang, Y. Effects of human activities on hydrological components in the Yiluo River basin in Middle Yellow river. Water 2019, 11, 689.

6. Caldas, A.; Pissarra, T.; Costa, R.; Neto, F.; Zanata, M.; Parahyba, R.; Sanches Fernandes, L.; Pacheco, F. Flood vulnerability, environmental land use conflicts, and conservation of soil and water: A Study in the Batatais SP Municipality, Brazil. Water 2018, 10, 1357.

7. Fernandes, A.C.P.; Sanches Fernandes, L.F.; Cortes, R.M.V.; Leal Pacheco, F.A. The role of landscape configuration, season, and distance from contaminant sources on the degradation of stream water quality in urban catchments. Water 2019, 11, 2025.

8. Valera, C.; Pissarra, T.; Filho, M.; Valle Júnior, R.; Oliveira, C.; Moura, J.; Sanches Fernandes, L.; Pacheco, F. The buffer capacity of riparian vegetation to control water quality in anthropogenic catchments from a legally protected area: A critical view over the Brazilian new forest code. Water 2019, 11, 549.

9. Pissarra, T.C.T.; Valera, C.A.; Costa, R.C.A.; Siqueira, H.E.; Martins Filho, M.V.; Valle Júnior, R.F. do; Sanches Fernandes, L.F.; Pacheco, F.A.L. A Regression model of stream water quality based on interactions between landscape composition and riparian buffer width in small catchments. Water 2019, 11, 1757.

10. Briciu, A.-E.; Graur, A.; Oprea, D.I.; Filote, C. A Methodology for the Fast Comparison of streamwater diurnal cycles at two monitoring points. Water 2019, 11, 2524.

11. Alvares Tenenwurcel, M.; Soares de Moura, M.; Monteiro da Costa, A.; Karen Mota, P.; Moreira Viana, J.H.; Fernandes, L.F.S.; Leal Pacheco, F.A. An improved model for the evaluation of groundwater recharge based on the concept of conservative use potential: A study in the river Pandeiros watershed, Minas Gerais, Brazil. Water 2020, 12, 1001.

12. Lopes Simedo, M.B.; Pissarra, T.C.T.; Mello Martins, A.L.; Lopes, M.C.; Araújo Costa, R.C.; Zanata, M.; Pacheco, F.A.L.; Fernandes, L.F.S. The assessment of hydrological availability and the payment for ecosystem services: A pilot study in a Brazilian headwater catchment. Water 2020, 12, 2726.

\section{References}

1. Álvarez, X.; Valero, E.; Santos, R.M.B.; Varandas, S.G.P.; Sanches Fernandes, L.F.; Pacheco, F.A.L. Anthropogenic nutrients and eutrophication in multiple land use watersheds: Best management practices and policies for the protection of water resources. Land Use Policy 2017, 69, 1-11. [CrossRef]

2. Oliveira, C.F.; do Valle Junior, R.F.; Valera, C.A.; Rodrigues, V.S.; Sanches Fernandes, L.F.; Pacheco, F.A.L. The modeling of pasture conservation and of its impact on stream water quality using partial least squares-path modeling. Sci. Total Environ. 2019, 697, 134081. [CrossRef] [PubMed]

3. Rodrigues, V.S.; do Valle Júnior, R.F.; Sanches Fernandes, L.F.; Pacheco, F.A.L. The assessment of water erosion using partial least squares-path modeling: A study in a legally protected area with environmental land use conflicts. Sci. Total Environ. 2019, 691, 1225-1241. [CrossRef] [PubMed]

4. Fonseca, A.R.; Sanches Fernandes, L.F.; Fontainhas-Fernandes, A.; Monteiro, S.M.; Pacheco, F.A.L. From catchment to fish: Impact of anthropogenic pressures on gill histopathology. Sci. Total Environ. 2016, 550, 972-986. [CrossRef] 
5. Ferreira, A.R.L.; Sanches Fernandes, L.F.; Cortes, R.M.V.; Pacheco, F.A.L. Assessing anthropogenic impacts on riverine ecosystems using nested partial least squares regression. Sci. Total Environ. 2017, 583, 466-477. [CrossRef]

6. Fonseca, A.R.; Sanches Fernandes, L.F.; Fontainhas-Fernandes, A.; Monteiro, S.M.; Pacheco, F.A.L. The impact of freshwater metal concentrations on the severity of histopathological changes in fish gills: A statistical perspective. Sci. Total Environ. 2017, 599, 217-226. [CrossRef]

7. Santos, R.M.B.; Sanches Fernandes, L.F.; Cortes, R.M.V.; Varandas, S.G.P.; Jesus, J.J.B.; Pacheco, F.A.L. Integrative assessment of river damming impacts on aquatic fauna in a Portuguese reservoir. Sci. Total Environ. 2017, 601, 1108-1118. [CrossRef]

8. Sanches Fernandes, L.F.; Fernandes, A.C.P.; Ferreira, A.R.L.; Cortes, R.M.V.; Pacheco, F.A.L. A partial least squares-Path modeling analysis for the understanding of biodiversity loss in rural and urban watersheds in Portugal. Sci. Total Environ. 2018, 626, 1069-1085. [CrossRef]

9. Fernandes, A.C.P.; Sanches Fernandes, L.F.; Moura, J.P.; Cortes, R.M.V.; Pacheco, F.A.L. A structural equation model to predict macroinvertebrate-based ecological status in catchments influenced by anthropogenic pressures. Sci. Total Environ. 2019, 681, 242-257. [CrossRef]

10. Pissarra, T.C.T.; Valera, C.A.; Costa, R.C.A.; Siqueira, H.E.; Martins Filho, M.V.; do Valle Júnior, R.F.; Sanches Fernandes, L.F.; Pacheco, F.A.L. A regression model of stream water quality based on interactions between landscape composition and riparian buffer width in small catchments. Water 2019, 11, 1757. [CrossRef]

11. Valera, C.; Pissarra, T.; Filho, M.; Valle Júnior, R.; Oliveira, C.; Moura, J.; Sanches Fernandes, L.; Pacheco, F. The buffer capacity of riparian vegetation to control water quality in anthropogenic catchments from a legally protected area: A critical view over the brazilian new forest code. Water 2019, 11, 549. [CrossRef]

12. Fernandes, A.C.P.; Sanches Fernandes, L.F.; Terêncio, D.P.S.; Cortes, R.M.V.; Pacheco, F.A.L. Seasonal and scale effects of anthropogenic pressures on water quality and ecological integrity: A study in the Sabor river basin (NE Portugal) using partial least squares-path modeling. Water 2019, 11, 1941. [CrossRef]

13. Fernandes, A.C.P.; Sanches Fernandes, L.F.; Cortes, R.M.V.; Leal Pacheco, F.A. The role of landscape configuration, season, and distance from contaminant sources on the degradation of stream water quality in urban catchments. Water 2019, 11, 2025. [CrossRef]

14. Cortes, R.; Peredo, A.; Terêncio, D.; Sanches Fernandes, L.; Moura, J.; Jesus, J.; Magalhães, M.; Ferreira, P.; Pacheco, F. Undamming the Douro river catchment: A stepwise approach for prioritizing dam removal. Water 2019, 11, 693. [CrossRef]

15. Fernandes, L.F.S.; Pinto, A.A.S.; Terêncio, D.P.S.; Pacheco, F.A.L.; Cortes, R.M.V. Combination of ecological engineering procedures applied to morphological stabilization of estuarine banks after dredging. Water 2020, 12, 391. [CrossRef]

16. Caldas, A.; Pissarra, T.; Costa, R.; Neto, F.; Zanata, M.; Parahyba, R.; Sanches Fernandes, L.; Pacheco, F. Flood vulnerability, environmental land use conflicts, and conservation of soil and water: A study in the Batatais SP municipality, Brazil. Water 2018, 10, 1357. [CrossRef]

17. Santos, R.M.B.; Sanches Fernandes, L.F.; Vitor Cortes, R.M.; Leal Pacheco, F.A. Hydrologic impacts of land use changes in the sabor river basin: A historical view and future perspectives. Water 2019, 11, 1464. [CrossRef]

18. Santos, R.M.B.; Fernandes, L.F.S.; Cortes, R.M.V.; Pacheco, F.A.L. Development of a hydrologic and water allocation model to assess water availability in the Sabor river basin (Portugal). Int. J. Environ. Res. Public Health 2019, 16, 2419. [CrossRef]

19. Terêncio, D.P.S.; Sanches Fernandes, L.F.; Cortes, R.M.V.; Pacheco, F.A.L. Improved framework model to allocate optimal rainwater harvesting sites in small watersheds for agro-forestry uses. J. Hydrol. 2017, 550, 318-330. [CrossRef]

20. Terêncio, D.P.S.; Sanches Fernandes, L.F.; Cortes, R.M.V.; Moura, J.P.; Pacheco, F.A.L. Rainwater harvesting in catchments for agro-forestry uses: A study focused on the balance between sustainability values and storage capacity. Sci. Total Environ. 2018, 613, 1079-1092. [CrossRef]

21. Soares, S.; Terêncio, D.; Fernandes, L.; Machado, J.; Pacheco, F. The potential of small dams for conjunctive water management in rural municipalities. Int. J. Environ. Res. Public Health 2019, 16, 1239. [CrossRef] [PubMed]

22. da Costa, A.M.; de Salis, H.H.C.; Viana, J.H.M.; Leal Pacheco, F.A. Groundwater recharge potential for sustainable water use in urban areas of the Jequitiba river basin, Brazil. Sustainability 2019, 11, 2955. [CrossRef] 
23. De Salis, H.H.C.; da Costa, A.M.; Künne, A.; Sanches Fernandes, L.F.; Leal Pacheco, F.A. Conjunctive water resources management in densely urbanized karst areas: A study in the Sete Lagoas region, State of Minas Gerais, Brazil. Sustainability 2019, 11, 3944. [CrossRef]

24. Cardoso de Salis, H.H.; Monteiro da Costa, A.; Moreira Vianna, J.H.; Azeneth Schuler, M.; Künne, A.; Sanches Fernandes, L.F.; Leal Pacheco, F.A. Hydrologic modeling for sustainable water resources management in urbanized Karst areas. Int. J. Environ. Res. Public Health 2019, 16, 2542. [CrossRef] [PubMed]

25. Alvares Tenenwurcel, M.; Soares de Moura, M.; Monteiro da Costa, A.; Karen Mota, P.; Moreira Viana, J.H.; Fernandes, L.F.S.; Leal Pacheco, F.A. An improved model for the evaluation of groundwater recharge based on the concept of conservative use potential: A study in the river Pandeiros watershed, Minas Gerais, Brazil. Water 2020, 12, 1001. [CrossRef]

26. Simedo, M.B.L.; Pissarra, T.C.T.; Martins, A.L.M.; Lopes, M.C.; Costa, R.C.A.; Zanata, M.; Pacheco, F.A.L.; Fernandes, L.F.S. The assessment of hydrological availability and the payment for ecosystem services: A pilot study in a brazilian headwater catchment. Water 2020, 12, 2726. [CrossRef]

27. Bellu, A.; Sanches Fernandes, L.F.; Cortes, R.M.V.; Pacheco, F.A.L. A framework model for the dimensioning and allocation of a detention basin system: The case of a flood-prone mountainous watershed. J. Hydrol. 2016, 533, 567-580. [CrossRef]

28. Terêncio, D.P.S.; Fernandes, L.F.S.; Cortes, R.M.V.; Moura, J.P.; Pacheco, F.A.L. Flood risk attenuation in critical zones of continental Portugal using sustainable detention basins. Sci. Total Environ. 2020. [CrossRef]

29. Salgado Terêncio, D.P.; Sanches Fernandes, L.F.; Vitor Cortes, R.M.; Moura, J.P.; Leal Pacheco, F.A. Can land cover changes mitigate large floods? A reflection based on partial least squares-path modeling. Water 2019, 11, 684. [CrossRef]

Publisher's Note: MDPI stays neutral with regard to jurisdictional claims in published maps and institutional affiliations. 